[Agr. Biol. Chem., Vol. 32, No. 3, p. 374 378, 1968]

\title{
Nutrition of Threonine
}

\section{Part V Possibility of Induction of Threonine Dehydratase in Rat Liver by Excess Administration of Lysine or Threonine}

\author{
By Michiko Yamashita, Teiichi Eto ${ }^{*}$, Masao Fujimaki \\ and Yosito SAKURaI ${ }^{* *}$ \\ Department of Agricultural Chemistry, The University of Tokyo, Tokyo \\ Received September 18, 1967
}

\begin{abstract}
Among the threonine dehydratase activities in liver of rat fed on basal diet (B-group), lysine added diet ( $\mathrm{L}$-group) and threonine added diet ( $\mathrm{T}$-group), a following relationship was found: $A_{B} \ll A_{L}<A_{T}$, where $A_{B}, A_{L}$ and $A_{T}$ were the activities of $B-, L-$ and T-group, respectively. The types of the activity increase in $\mathrm{L}$ - or $\mathrm{T}$-group were investigated by examining the possibility of the cause-the existence of activators in L-or T-group (I), the existence of inhibitors in B-group (II), the activation of the latent enzyme in L- or Tgroup (III), and the induction of the dehydratase by biosynthesis in L- or T-group (IV). Addition of various amounts of liver homogenate of L- or T-group to a given amount of that of B-group gave a result as would be obtained in cases where neither activators nor inhibitors existed in the liver ( $I$ and II). No correlationship was found between the activity and the preincubation time, which denied the presence of the latent enzyme which would easily change into the active form by preincubation (III). Actinomycin D administered to rats inhibited the increase of the dehydratase activity of L- or T-group by about $50 \%$ (IV). On the other hand, preliminary experiments using hypophysectomized or adrenalectomized rats showed the results of $\mathrm{A}_{B} \div \mathrm{A}_{L} \div \mathrm{A}_{\mathrm{T}}$. Both results may suggest the possibility that the increase of the dehydratase activity is ascribed to the induction of this enzyme through biosynthesis, and perhaps through endocrine systems.
\end{abstract}

In a series of studies on threonine catabolism in rat liver, the authors have found that the threonine decomposition ability of rat liver increases, both in vivo and in vitro, by excess administration of lysine and/or threonine, which suggests the participation of lysine in threonine catabolism. ${ }^{1 \sim 4}$ According to the

* Department of Veterinary Physiology, The University of Tokyo, Tokyo.

** Department of Home Economics, The Japan Women's University, Tokyo.

1) M. Yamashita and Y. Sakurai, J. Jap. Soc. Food Nutr., 19, 167 (1966).

2) M. Yamashita and Y. Sakurai, ibid., 19, 215 (1966).

3) M. Yamashita and Y. Sakurai, ibid., 19, 218 (1966).

4) M. Yamashita and Y. Sakurai, Agr. Biol. Chem., 30, 937 (1966). previous report, the increase of this ability was ascribed to the increase of threonine dehydratase activity as measured by the amount of $a$-ketobutyric acid produced, and had no relationship with other enzymes of threonine aldolase, threonine dehydrogenase, ornithine transaminase and so on. ${ }^{5 !}$

Generally, the types of the increase of enzyme activity are classified as follows: I, the existence of activators; II, the disappearance of inhibitors; III, the activation of latent enzyme; and IV, the induction of enzyme protein, which was devided into (a) the induction by biosynthesis and (b) the substrate

5) M. Yamashita, M. Fujimaki and Y. Sakurai, Agr. Biol. Chem., 31, 1047 (1967). 
type induction. Greengard and Feigelson ${ }^{6}$ reported on the activation of tryptophan pyrrolase in rat liver by hematin (Type I). Kato et al. ${ }^{7 \prime}$ reported on the inhibition of cystathionine synthetase by sulfur which had accumulated through excess administration of cystine (Type II). Cygan and $\mathrm{Zak}^{81}$ reported on asyartate transcarbamylase in beef liver which changed into the active form during preincubation (Type III). Garren et al. ${ }^{\text {' }}$ reported that hepatic tyrosine transaminase of rat was formed by hormonal induction (Type IV-a). Knox et al. ${ }^{101}$ reported that tryptophan pyrrolase in rat liver was partly concerned in substrate type induction (Type IV-b). Among those types, the type IV-a appears most frequently, which is known to be inhibited by administration of some sort of antibiotics such as actinomycin $\mathrm{D},{ }^{11}$ puromycin, ${ }^{121}$ chloramphenicol, ${ }^{131}$ etc., and by resection of organs regulating the biosynthesis. ${ }^{14}$

The present paper deals with the estimation of the type of the activity increase of threonine dehydratase in rat liver by excess administration of lysine or threonine.

\section{EXPERIMENTAL}

Male rats of the Wister strain weighing about $200 \mathrm{~g}$, which had been fed on the basal diet for the first one week and then on the experimental diets for the following one week, were used. The compositions of the basal diet, the lysine added diet and the

6) O. Greengard and P. Feigelson, J. Biol. Chem., 236, 158 (1961).

7) A. Kato, T. Matsuzawa, M. Suda, H. Nakagawa and J. Ishizuka, J. Biochem., 55, 401 (1964).

B) Z. Cygan and T. Zak, Biochim. Biophys. Acta, 134, 289 (1967).

9) L.D. Garren, R. R. Howell and G. M. Tomkins, J. Mol. Biol., 9, 100 (1964).

10) W. E. Knox, M. Ogata, N. Hasegawa and K. Tokuyama, Sixth International Congress of Biochemistry, New York, 1964.

11) E.P. Mishkin and M. L. Shore, Biochim. Biophys. Acta, 138, 169 (1967).

12) A. Grossman and C. Mavrides, J. Biol. Chem., 242, 1398 (1967).

13) S. A. Armentrout and A. S. Weisberger, Biochem. Biophys. Res. Commun., 26, 712 (1967).

14) R. A. Freedland and E. H. Avery, J. Biol. Chem., 2393357 (1964). threonine added diet were similar to those shown in the previous paper. ${ }^{5}$ ) The determination method of threonine dehydratase activity was also resembling that described in the previous report. ${ }^{5}$ The MichaelisMenten constant of the dehydratase was obtained from the Lineweaver-Burk plot.15) The investigation of whether or not the increase of the dehydratase activity was ascribed to the type I or II was carried out as follows.

Experiment 1. Investigation of heat stable activators (HSA). Fifteen $m l$ of the enzyme solution prepared from the rat liver of the lysine added diet group or the threonine added diet group was heated in boiling water for $5 \mathrm{~min}$ and filtrated, the resulting filtrate being designated HSA(Lys) or HSA (Thr), respectively. To $2 \mathrm{ml}$ of the enzyme solution of the basal diet group was added $2 \mathrm{ml}$ of HSA(Lys) or HSA(Thr) and the threonine dehydratase activity of the mixture was determined.

Experiment 2. Investigation of dilution effects. Each enzyme solution from the basal, the lysine added or the threonine added diet group was diluted with the buffer solution to various stages of concentration, and the relationship of the threonine dehydratase activities vs. the concentrations was examined. A similar investigation was carried out by adding various amounts of the enzyme solution of the lysine or the threonine group to a given amount of the original enzyme solution of the basal group.

In order to examine the type III, the enzyme solution was preincubated for various times, the other experimental conditions being similar to those in the previous report. ${ }^{5}$

The possibility of the induction of threonine dehydratase by biosynthesis was estimated from the effects of actinomycin $\mathrm{D}$ on the activity of the enzyme. Two $\mathrm{mg}$ of crystalline actinomycin $\mathrm{D}$ was dissolved in small volume of acetone. To the solution was added $25 \mathrm{ml}$ refined sesame oil, and acetone was evaporated completely under reduced pressure. The oil solution was emulsified with $175 \mathrm{ml}$ of water and $\mathrm{lg}$ of lecithin. Two $\mathrm{ml} / \mathrm{day}$ of the emulsion for an individual animal, equivalent to $20 \mu \mathrm{g}$ of actinomycin D, was administered peroral for 7 days, where the experimental diet was given in an usual manner and the weight of rat was checked up each day.

The preliminary investigation on the possibility of the hormonal induction of the dehydratase was also

15) H. Lineweaver and D. Burk, J. Am. Chem. Soc., 56, 658 (1934). 
carried out by hypophysectomy or adrenalectomy. The hypophysectomized or adrenalectomized rats were fed on the basal diet for the first 10 days until the complete restoration was attained, and fed on the experimental diet for the following 7 days. Through these periods the adrenalectomized rats received $1 \%$ $\mathrm{NaCl}$ in the drinking water. After determination of the dehydratase activity, the rat was submitted to the examination under a magnifying glass of 10 magnification for affirming that the hypophysis on pituitary fossa or adrenals and accessory adrenals had been completely removed; and the hypophysectomized rat were also examined the weights of adrenals, testicles and prostate.

\section{RESULTS}

The $K m$-values in the reactions between threonine dehydratase and its substrate, threonine, were as follows: $K m=1.04 \times 10^{-1} \mathrm{M}$, $1.01 \times 10^{-1} \mathrm{~m}$ and $1.04 \times 10^{-1} \mathrm{M}$ for the basal, the lysine added and the threonine added diet group, respectively. No significant difference was found among these values.

Table I showed that the addition of either HSA(Lys) or HSA(Thr) to the enzyme solution of the basal diet group had no significant effect on the dehydratase activity of it.

As shown in Fig. 1, a linear relationship was obtained between the enzyme concentration and the activity for each case. The curves $B, L$ and $T$ passed through the origin of coordinates, and the curves BL and BT were parallel with the curves $\mathrm{L}$ and $\mathrm{T}$, respectively.

Table I. EFFECT OF HEat STable Fraction OF EIVER HOMOgENATE ON THREONINE DEHYDRATASE ACTIVITY

Enzyme solution

$\begin{array}{ll}\text { Enzyme solution of the basal } & 6.38 \\ \text { diet group+HSA (Lys) } & 6.71 \\ \text { Control* } & 6.82 \\ \begin{array}{l}\text { Enzyme solution of the basal } \\ \text { diet group+HSA (Thr) }\end{array} & 6.60\end{array}$

* Added with buffer solution instead of HSA.

** $\mu \mathrm{moles} / \mathrm{min} / \mathrm{g}$ liver (The same representation was used in following Tables.)

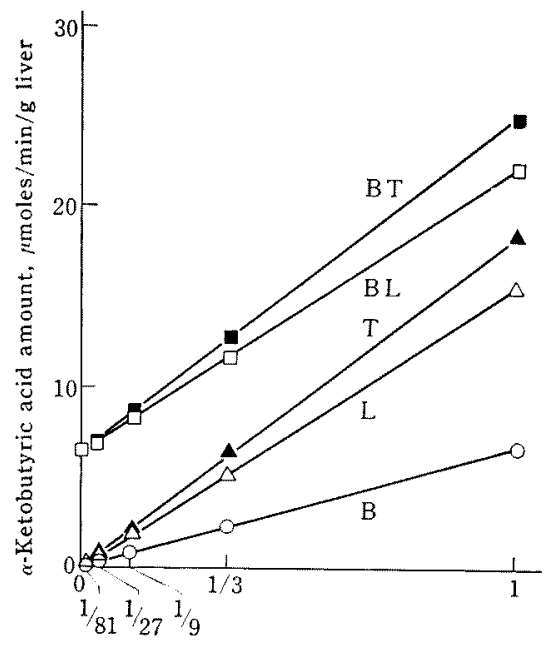

Reciprocal of dilution, $1 / \mathrm{D}$

FIG. 1. Investigation on Activators or Inhibitors.

$\mathrm{D}=1$ shows the original enzyme solution and $\mathrm{D}=3$, for example, shows that the enzyme solution has been diluted with buffer solution 3 times as much as the original one. $B, L$ and $T$ show the enzyme solutions of the basal, the lysine added and the threonine added diet group, respectively. $\mathrm{BL}$ or $\mathrm{BT}$ shows that $\mathrm{L}$ or $\mathrm{T}$ at the various stages of dilution has been added to $B$ of $D=1$.

Table II. EFFect of PReincubation Time ON THREONINE DEHYDRATASE ACTIVITY

$\begin{array}{ccc}\begin{array}{c}\text { Preincubation } \\ \text { time (min) }\end{array} & \begin{array}{c}\alpha \text {-Ketobutyric acid amount } \\ \text { Basal diet } \\ \text { group }\end{array} & \begin{array}{c}\text { Lysine added diet } \\ \text { group }\end{array} \\ 0 & 5.97 & 12.11 \\ 7.5 & 6.30 & 13.58 \\ 15 & 6.24 & 13.56 \\ 30 & 6.47 & 13.71\end{array}$

Table II showed that no significant difference in the activity was found among the preincubation times of $7.5,15$ and $30 \mathrm{~min}$ for each case. The value at $0 \mathrm{~min}$ was eliminated since the optimum temperature could not be attained.

As shown in Table III, actinomycin D inhibited the increase of the activity, the degree of inhibition being approximately $50 \%$ on the average in each case, although the inhibition 
was dependent on the weight grains of rats (Fig. 2).

Table IV showed that there was no significant difference in the activity among the diets, when rats had been hypophysectomized or adrenalectomized.

TABLE III. EFFECT OF ACTINOMYCIN D ON THREONINE DEHYDRATASE ACTIVITY

\begin{tabular}{|c|c|c|c|c|c|}
\hline Treatment & Diet* & $\begin{array}{l}\alpha \text { Keto- } \\
\text { butyric } \\
\text { acid } \\
\text { amount }\end{array}$ & $\mathrm{n}^{* *}$ & $\mathrm{R} * * *$ & $\begin{array}{l}\text { Degree } \\
\text { inhibitic } \\
(0,)^{* *}\end{array}$ \\
\hline \multirow[t]{3}{*}{ Actinomycin D } & B & 4.37 & 2 & 0.69 & \\
\hline & $\mathrm{L}$ & 5.10 & 4 & 2.56 & 41.5 \\
\hline & $\mathrm{T}$ & 5.91 & 2 & 1.80 & 46.6 \\
\hline \multirow[t]{3}{*}{ Control } & B & 6.75 & 4 & 2.29 & \\
\hline & $\mathrm{L}$ & 13.46 & 3 & 3.04 & \\
\hline & $\mathrm{T}$ & 17.11 & 3 & 3.36 & \\
\hline
\end{tabular}

* B, L and T mean basal, lysine added and threonine added diet, resp.

** Number of experimental animals.

*** Range ( $\mu$ mole).

**** Calculated from $\left(1-\frac{A^{\prime} L, T}{A^{\prime}{ }_{B}} / \frac{A_{L, T}}{A_{B}}\right) \times 100$, where $A_{B}^{\prime}$ and $A_{L, T}^{\prime}$ are the threonine dehydratase activities of $B$ and $L, T$ group in the case of actinomycin $D$ treatment, and $A_{B}$ and $A_{L, T}$ are those in the control.

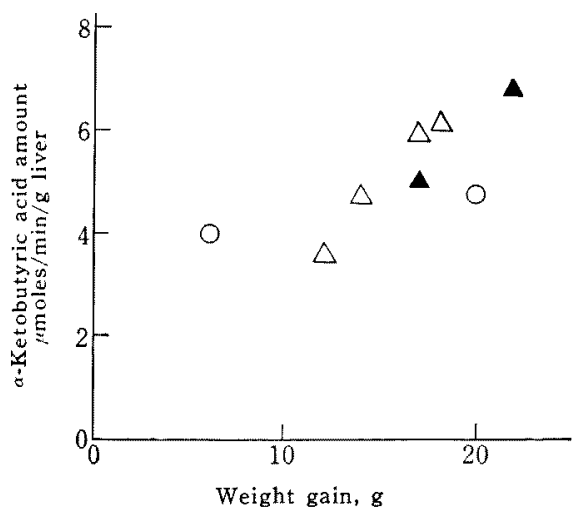

Fig. 2. Correlationship between Threonine Dehydratase Activities and Weight Gains of Rats Administered with Actinomycin D.

$0, \triangle$ and $A$ show the basal, the lysine added and the threonine added diet group, respectively.
TABLE IV. EFFECT OF HYPOPHYSECTOMY OR ADRENALECTOMY ON THREONINE DEHYDRATASE ACTIVITY*

$\begin{array}{ccccc}\text { Treatment } & \text { Diet } & \begin{array}{c}\alpha \text {-Ketobutyric } \\ \text { acid amount }\end{array} & \mathrm{n} & \mathrm{R} \\ \text { Hypophysectomy** } & \mathrm{B} & 5.18 & \mathrm{I} & \\ & \mathrm{L} & 5.34 & 2 & 0.18 \\ & \mathrm{~T} & 5.32 & 2 & 0.11 \\ \text { Adrenalectomy } & \mathrm{B} & 3.77 & 1 & \\ & \mathrm{~L} & 3.44 & 2 & 1.23 \\ & \mathrm{~T} & 3.30 & 2 & 0.43\end{array}$

* The meanings of $B, L, T, n$ and $R$ are similar to those described in Table III. See Table III as for the control.

** The average weights of testicles, prostate and adrenals were $632 \mathrm{mg}(\mathrm{R}=387 \mathrm{mg}$ ), $28 \mathrm{mg}$ ( $\mathrm{R}=$ $10 \mathrm{mg})$ and $14 \mathrm{mg}(\mathrm{R}=5 \mathrm{mg})$ for hypophysectomized animals, whereas those were 2400 $\mathrm{mg}, 350 \mathrm{mg}$ and $50 \mathrm{mg}$ for the control animals, respectively.

\section{DISCUSSION}

Nagabhushanam and Greenberg ${ }^{161}$ reported that threonine dehydratase in rat liver, purified about 1800 -fold, was homogeneous in the ultracentrifugal pattern, and the isozyme of this enzyme has not been found. The accordance of $K m$, as described above, also affirms that the protein having threonine dehydratase activity of the lysine or threonine added diet group is identical with that of the basal diet group. Accordingly, the increase of the dehydratase activity by excess administration of lysine or threonine can be ascribed to the types I, II, III and/or IV mentioned in the introduction.

The existence of HSA(Type I) was denied (Table I).

Either the effects of activators (Type I) or those of inhibitors (Type II) might be negative since any deviation form the parallel of declination, as would be expected when activators or inhibitors were present, was not observed (Fig. 1).

The latent enzyme (Type III) seemed to be absent, because no relationship was found

16) A. Nagabhushanam and D. M. Greenberg, $J$. Biol. Chem., 240, 3002 (1965). 
between the preincubation time and the activity (Table II). In many cases, intracellular latent enzymes in higher animals are considered to change easily into active forms during the preincubation of cell homogenate, an example of which has been reported by Cygan and $\mathrm{Zak}^{81}$

Through the investigations on the types of I, II and III, any positive results were not obtained, although these results were estimated from the previous report ${ }^{31}$ that the increase of the dehydratase activity by excess feeding of lysine or threonine was not so prompt but several days had been required until the maximum activity was attained, in spite of the fact that sufficient amount of lysine or threonine always existed in blood.

It is probable from the above result that the activity of the enzyme increases by biosynthesis of enzyme protein (Type IV-a), although the coexistence of the type IV-b may be possible, in which this paper does not concern. The induction of enzyme through biosynthesis was generally investigated by determining the rate of incorporation of ${ }^{14} \mathrm{C}$, ${ }^{11}$ the enzyme amount by the immunochemical method, ${ }^{17}$ and the degree of inhibition of the enzyme biosynthesis with antibiotics, ${ }^{11-133}$ etc. As mentioned before, $20 \mu \mathrm{g} / \mathrm{day}$ of actinomycin $\mathrm{D}$ for an animal was administered for 7 days, which resulted in inhibiting to a considerable degree the increase of the activity by excess feeding of lysine or threonine (Table III). The dose of actinomycin D was suitable so that the diet consumption of each experimental animal was maintained in normal condition, and a certain degree of body weight increase was observed. Some correlationship between the weight gains and the activities was found (Fig. 2), which might

17) D. Holten, W. D. Wicks and F. T. Kenney, J. Biol. Chem., 242, 1053 (1967). be resulted from the difference among animals in absorption amount of actinomycin D and in responsibility to it.

Biosynthesis of enzyme of higher animals is known to be regulated by hormons or by nervous systems, the former is participated in slow adaptation and the latter in rapid adaptation against nutritive disturbance. The fact that eventhough a large amount of lysine or threonine soon appears in blood ${ }^{181}$ and in urine $^{3 \prime}$ after excess feeding of this amino acid, the increase of the activity does not so rapidly compensate this nutritive disturbance, seems to suggest the possibility of hormonal induction. The facts have been known that there often are the cases where some sorts of nutritive substances act roles of signals which stimulate endocrine systems. According to the present studies using hypophysectomized and adrenalectomized rats, the effects of excess feeding lysine or threonine on the increase of threonine dehydratase activity were not observed (Table IV). This indicates that the adrenals participate in the activity increase and furthermore, in combination with the results using actinomycin $\mathrm{D}$, the adrenal hormons would induce the biosynthesis of this enzyme.

Acknowledgements. The authors wish to express their thanks to Professor B. Maruo of The Institute of Applied Microbiology, The University of Tokyo, for his kind supply of actinomycin D, to associate Professor Y. Suzuki of Department of Veterinary Physiology, The University of Tokyo, for his helpful guidance, and also to Mr. G. Noguchi for his technical assistance.

This research has been financed in part by Tanabe Amino Acid Research Foundation.

18) E. Tamura, Y. Obata, T. Niizeki and N. Matsuno, Amino Acids (Japan), 7, 4 (1967). 